\title{
Electrification in Urban Transport: A Case Study with Real-time Data
}

\author{
İ.C. DİKMEN, Y.E EKİCI, T. KARADAĞ, T. ABBASOV and S.E. HAMAMCI
}

\begin{abstract}
Electrification in urban transportation is becoming more popular, it is also becoming a necessity due to climate changes and sustainability issues. Trolleybuses are presenting an alternative for this purpose. Although their technology is a mature technology that has been used for decades, there are still some technical problems that need to be overcome. In this study, a technical method is presented for the conversion of trolleybus auxiliary power units. The electrification conversion demanded by the metropolitan public transportation company operating 22 trolleybuses in the province of Malatya is the replacement of diesel generators, used as auxiliary power units, with battery units capable of meeting the local operational requirements. For this purpose, a method is proposed and followed. At the first step of the implementation, real-time data has gathered from a trolleybus and this one round tour data is used to run on a scaled experiment. The setup has prepared as hardware and software to simulate the consumption on a scaled battery pack. Experimental results were interpreted with capacity and voltage restrictions resulting in the determination of battery chemistry and casing to be used. Then optimal battery placement was defined as a container loading problem and application was made with the first fit decreasing algorithm considering mass and volume restrictions. It was found that only two packing types out of six combinations are enough to form a battery pack within the mass and volumetric limitations. It is evaluated that the method
\end{abstract}

İSMAİL CAN DİKMEN, is with Department of Electric Vehicle Technologies Inonu University OSB Vocational School, Malatya, Turkey, (e-mail: can.dikmen@inonu.edu.tr).

(iD https://orcid.org/0000-0002-7747-7777

YUNUS EMRE EKİCi, is with Department of Electric Vehicle Technologies Inonu University OSB Vocational School, Malatya, Turkey,

(e-mail: emre.ekici@inonu.edu.tr).

(iD) https://orcid.org/0000-0001-7791-0473

TEOMAN KARADA $\breve{G}$, is with Department of Electric Electronic Engineering Inonu University, Malatya, Turkey,

(e-mail: teoman.karadag@inonu.edu.tr).

https://orcid.org/0000-0002-7682-7771

TAHMURAZ ABBASOV, is with Department of Electric Electronic

Engineering Inonu University, Malatya, Turkey,

(e-mail: teymuraz.abbasov@inonu.edu.tr).

(iD) https://orcid.org/0000-0002-0290-8333

SERDAR ETHEM HAMAMCI, is with Department of Electric Electronic Engineering Inonu University, Malatya, Turkey,

(e-mail: serdar.hamamci@inonu.edu.tr).

iD https://orcid.org/0000-0002-1868-6843

Manuscript received December 07, 2020; accepted January 12, 2021. DOI: $\underline{10.17694 / \text { bajece. } 837248}$ adopted in this study can be used in conversion applications to be made in the future.

Index Terms - Auxiliary power unit, container loading problem, conversion, electrification, first-fit decreasing algorithm, trolleybus.

\section{INTRODUCTION}

VARIOUS TECHNOLOGIES have been developed for transportation. While animals were used for this purpose, a self-propelled vehicle was no more than a dream. Like with all inventions, somebody's dream came true. The first-ever self-propelled vehicle invented by French engineer and mechanic Nicolas Joseph Cugnot in 1769 [1]. That vehicle shown in Figure 1 is considered as the first steampowered automobile; actually, it was a military cart intended for transporting cannons.

Electric-powered vehicles were always being popular since the invention of the electric motor. But the biggest challenge was and is still storing electric power on the vehicle. In 1799 Alessandro Giuseppe Antonio Anastasio Volta presented the system he discovered which is capable of storing electric power [2], [3]. This was the first battery, unfortunately, it was not suitable for a selfpropelled electric vehicle not only because of its insufficient electrical properties but also its weight and volume. This was an engineering problem and could be solved in various ways. A German engineer named Dr. Ernst Werner von Siemens solved it in a wise way [4].

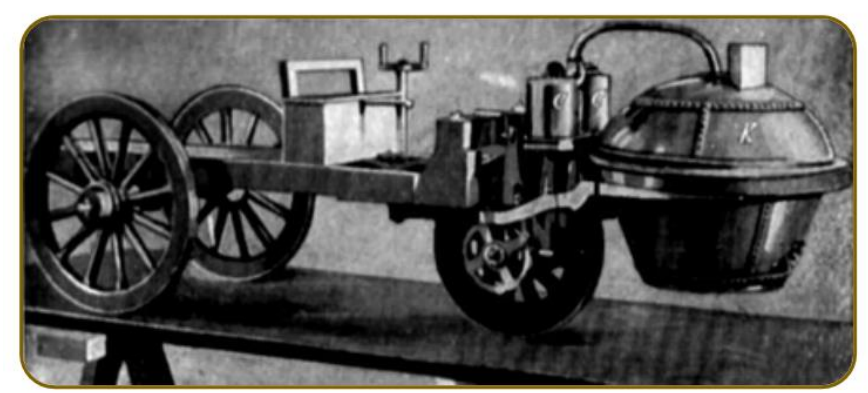

Fig.1. Steam Powered Automobile

The idea goes back to 1847 but realizations took some more time. Finally, Siemens presented his invention to the public April 29th 1882 in Halensee. He named his invention as ELECTROMOTE, shown in Figure 2. That was an electric 
vehicle made with a four-wheeled horse cart and powered by two electric motors. These motors were rated $2.2 \mathrm{~kW}$ and mechanical power transmission was made via steel chains connected to the rear wheels. In order to fulfill the DC power needs, he made his move and installed an overhead line instead of a battery pack. This line was carrying 550 Volt direct current and was transferring it to the vehicle with an apparatus made of eight wheels. The apparatus moving along this bipolar cable served as a current collector [5]. So, he managed to create a fully electric transportation system. It was installed at the suburbs of Berlin between Halensee railway station (today known as Kurfürstendamm) and Straße No. 5 (today known as Joachim-Freidrich-Straße). This was the first trolleybus line in history [6].

The technology behind the trolleybus systems has not changed drastically since those days [7]. If one looks at today's modern trolleybuses can see that AC motors with inverters took place of DC motors, metal wheels changed to regular bus tires; this let trolleybuses navigate through regular roads instead of railways [8], [9]. Therefore, trolleybuses became more like buses, rather than trains. By this way trolleybuses can be used all over the residential areas.

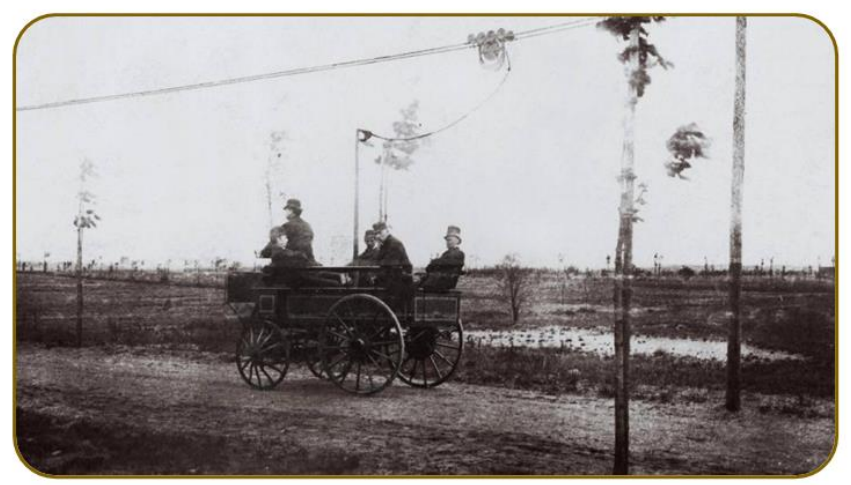

Fig.2. Electktromote (Photo courtesy of Siemens AG)

In the last decades, regulations have been made to obtain more reliable, secure, and environmental transportation for the public while considering the global climate changes [10], [11]. The European Union has a target of $80 \%$ electrification of all public transport by 2030 [12], [13]. Moreover, countries targeting to phase out fossil fuel-powered vehicles by year Norway, 2025; Denmark, Iceland, Ireland, Israel, Nepal, Netherlands, Slovenia, Sweden, 2030; Scotland, 2032; Colombia, United Kingdom, 2035; British Columbia, California, Canada, France, Portugal, Spain, Sri Lanka, Taiwan (Province of China), 2040; Cabo Verde, Costa Rica, Japan, Mexico, 2050 [14].

Trolleybuses used for urban transportation is a taken step forward on this vision. But, some trolleybuses still have optional diesel auxiliary power units [15]-[17]. This unit helps to drive vehicles without connecting to the overhead line. It is used mainly while maneuvering on stucked roads or in workshops. In addition, an extra inverter or converter system is not required as it operates on the same electronic systems [18]. But its most important duty is to letting the vehicle to move in case of power failure. These auxiliary power units may be diesel generators as well as battery packs [19]. Because of environmental issues and developing battery technologies, conversion of diesel generators to battery pack is became more important and more affordable [20]. In this regard, a case study is chosen as the main problem of this article.

\section{MATERIALS AND METHODS}

\section{A. Method}

In this paper, the following method has been adopted.
1| Problem statement
2 Numerical analysis
3 Scaled hardware analysis (in $1.5 \%$ error range)
4| Determination of battery case and pack type with power, voltage, and weight constraints
5 | Optimal battery placement with volume constraint

Here, first, the problem is presented. Then a numerical analysis has done. Due to commercial availability only lithium iron phosphate prismatic and 18650 case batteries or lithium manganese cobalt oxide batteries in 18650 casing were useable in this study. With these battery types, a scaled hardware analysis has conducted to prove that requirements are met. Afterward battery type and the casing have determined with respect to the results obtained. For the last step, a container loading problem has defined as an integer linear programming problem and solved by using the first fit decreasing heuristic algorithm.

\section{B. Problem Statement}

A trolleybus is an electric bus that gets its power from two wires in an overhead power line that is usually hung along the road [21], [22]. The reason for using two cables is that unlike trams, it is impossible to complete the circuit with a single cable due to the use of insulating rubber wheels [23]. The number of trolleybus systems worldwide is 286 . Most of these systems are located in post-socialistic countries [24], [25].

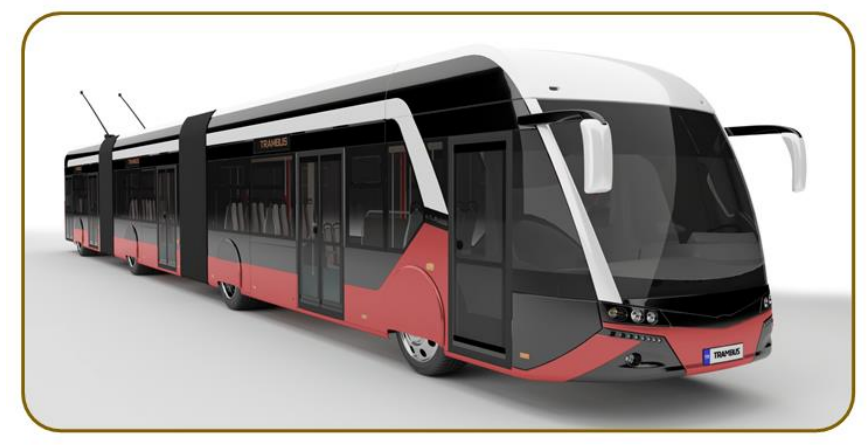

Fig.3. Trolleybus (Photo courtesy of MOTAŞ) 
Trolleybuses have been used in Turkey for many decades [26]. After a break for almost twenty years, in the spring of 2015, a new trolleybus project has been launched in Malatya city [27], [28]. In this study, the Trolleybus presented in Figure 3 and operated by Malatya Metropolitan Municipality Public Transportation Inc. will be taken into account for the case study. These vehicles have a motor of $320 \mathrm{~kW}$ and are 24.7 meters long. It also uses a diesel generator as an auxiliary system.

In order for the trolleybus to operate efficiently, the appropriate route must first be selected. The route is chosen according to the parameter of passenger density per kilometer in an hour. Therefore, it is determined that the best route is between the two main city locations on the two edges of the city in the east-west direction. These are Inonu University at the east of Malatya city and the City Bus Terminal at the west [28]. The route which is $38.2 \mathrm{~km}$ long and takes 96 minutes for a trolleybus to travel is shown in Figure 4.

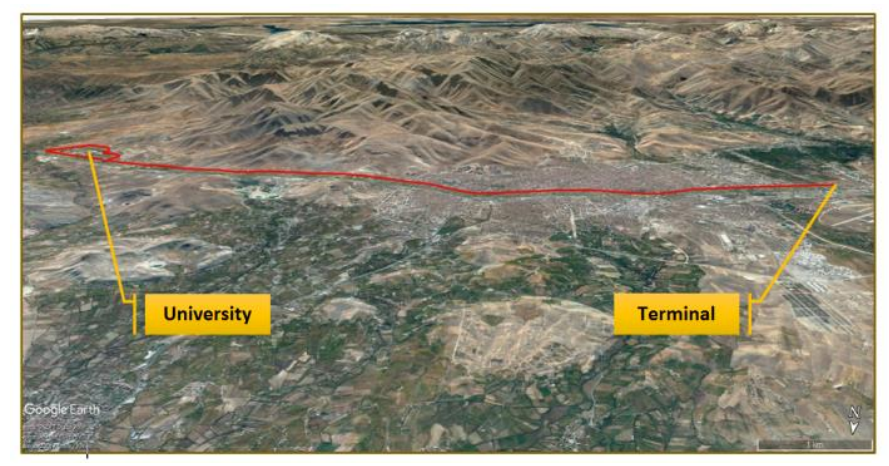

Fig.4. Malatya city trolleybus route

In the first phase of the project, infrastructure works were completed and ten vehicles were purchased. These vehicles are equipped with two $160 \mathrm{~kW}$ electric motors and a $50 \mathrm{~kW}$ diesel auxiliary power unit. The weight of the generator is $600 \mathrm{~kg}$. The fully loaded weight of the fuel tank placed separately from the generator is $50 \mathrm{~kg}$. Therefore, $650 \mathrm{~kg}$ was determined as the weight constraint in the calculations to be made in this study. In vehicles equipped with a diesel generator as an auxiliary power system. In the second phase of the project, ten more vehicles were purchased but these vehicles are equipped with $110 \mathrm{kWh}$ battery auxiliary power unit and have two $250 \mathrm{~kW}$ electric motors. First batch of the vehicles is having trouble with these generators. Because generators are not fully capable of powering these double articulated trolleybuses. Besides, regenerative braking energy (recuperation energy) cannot be used efficiently due to a lack of a proper energy storage system [29]-[31]. Therefore, it became necessary to convert these generators into battery blocks. In order to realize this purpose a numerical and experimental study was carried out with power constraint of minimum $110 \mathrm{kWh}$, voltage constraint of minimum 550 Volts, weight constraint of maximum $650 \mathrm{~kg}$. and volumetric constraint of $1,1782 \mathrm{~m}^{3}$.

\section{Experimental Setup}

All trolleybuses have a data recorder installed. These data recorders can collect speed, power, torque, acceleration, energy consumption, temperature, actual power, and recuperation power data with timestamps.

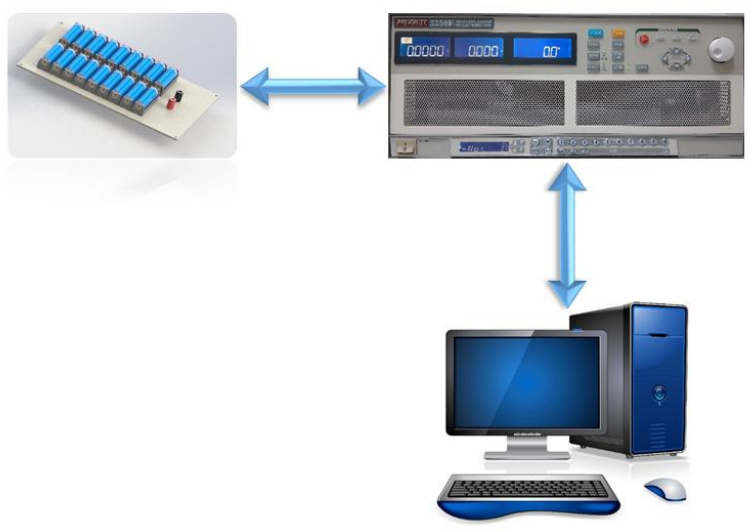

Fig.5. Experiment setup

As we have the real-time data of the vehicle for one tour, an experimental setup shown in Figure 5 is designed in order to run the real-time data in a scaled experiment. To scale down the real-time data, a hardware is designed and manufactured to place 18 cells in series, connected to a programmable electronic DC load. A software is also designed in LabVIEW for the electronic load to run a tour on the scaled battery pack.

\section{SCALED EXPERIMENT}

Real-time accelerator pedal data, vehicle speed and consumption data were obtained from the data loggers on the trolleybuses [32]. In Figure 6, the speed, acceleration and power consumption data of a trolleybus along a route are presented. As can be seen here, while the vehicle's two electric motors had total power of $320 \mathrm{~kW}$, the maximum power consumption measured was $407.7 \mathrm{~kW}$. The reason for this is other equipment that consumes energy on the vehicle. For example, Heating, Ventilating and Air Conditioning systems (HVAC). The speed of the vehicle is limited to $75 \mathrm{~km} / \mathrm{h}$ and its positive acceleration is $1.5 \mathrm{~m} / \mathrm{s}^{2}$ by software. Negative acceleration varies according to the condition of the road, the braking characteristics of the driver. A maximum of $-2.502 \mathrm{~m} / \mathrm{s}^{2}$ deceleration is measured. Additionally, due to road construction at the time, between $16.61 \mathrm{~km}$ and $18.77 \mathrm{~km}$, the vehicle goes off-wire and is powered by the $50 \mathrm{~kW}$ generator. This is the reason why the vehicle's power consumption, acceleration and speed are limited during that time. While the vehicle moves with generator power, HVAC and other ancillary systems are limited by software so that more power can be supplied to the vehicle's traction system. 

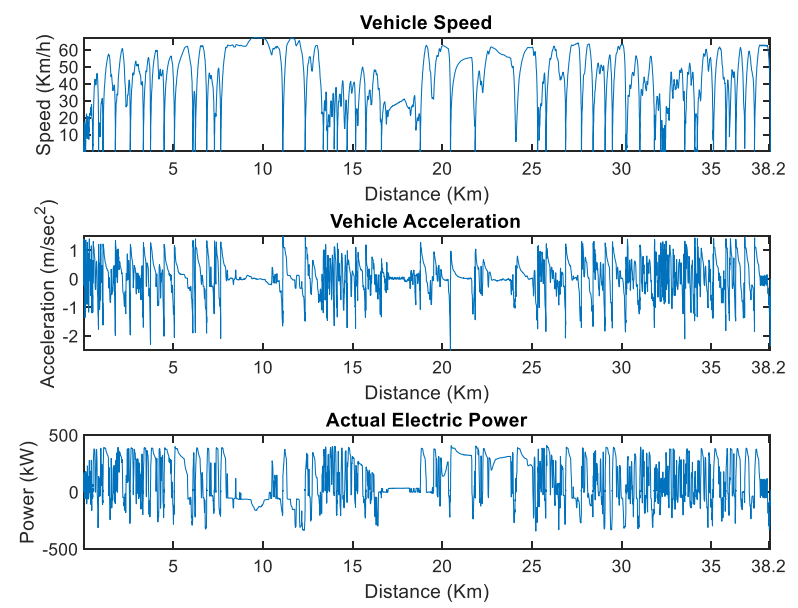

Fig.6. Real-time speed, acceleration and power data for one round

Two different battery groups with different chemical properties used for the scaled experiment. Type 1 is $\mathrm{LiNiMnCoO}$ batteries and Type 2 is $\mathrm{LiFePO}_{4}$ batteries which are rated $3.7 \mathrm{~V}$ nominal voltage $3250 \mathrm{mAh}$ capacity and $3.2 \mathrm{~V}$ nominal voltage $1500 \mathrm{mAh}$ capacity respectively. Both types are tested with a battery analyzer. It was found out that Type 1 batteries have $3230 \mathrm{mAh}$ capacity while Type 2 batteries have only 730 . Therefore, first experiment ran with datasheet values of the Type 2 batteries to show that the rated capacities written on them are not sound. Then the second experiment is run with the averaged data gathered from the first experiment in order to correct the data mismatch within real and datasheet values. Both experiments are halted due to batteries' rundown.

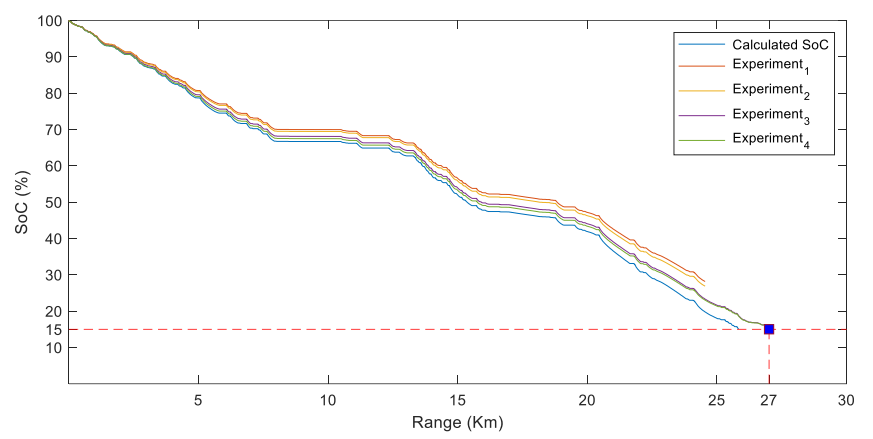

Fig.7. Calculated State of Charge (SoC) and experimental results

In the third experiment; data from the battery analyzer is used. It was found out that gathered data is much closer to the realtime data. On the fourth run Type 1 batteries are used with found parameters and results are presented in Figure 7. Mean Square Errors and Root Mean Square Errors of all four experiments are shown in Figure 8. The average error for this experiment is found to be $1.27 \%$. So, it was accurate enough to calculate the battery capacity for the conversion purpose.

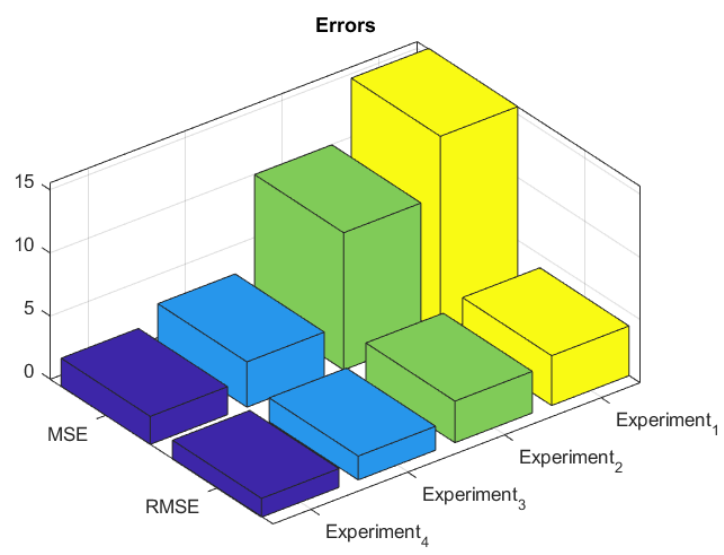

Fig.8. Experimental errors with respect to real-time data

\section{BATTERY PACKING}

The diesel generator has to be disassembled to convert the auxiliary power unit of the trolleybus to a battery pack. In addition to the diesel generator, there is also a fuel tank that supplies fuel to this generator. While the conversion the volume and weight distributions are became constraints. For this reason, the optimum amount of battery that can fit into the generator compartment and how to pack these batteries in groups is a problem that needs to be solved.

\section{TABLE I GENERATOR COMPARTMENT AND FUEL TANK DIMENSIONS}

\begin{tabular}{lccccc} 
& & \multicolumn{3}{c}{ Dimension $(\mathrm{cm})$} & Volume \\
\cline { 3 - 5 } & Section & $\mathbf{L}$ & $\mathbf{W}$ & $\mathbf{H}$ & $\left(\boldsymbol{m}^{3}\right)$ \\
\hline Fuel Tank & $\mathrm{F}$ & 50 & 64 & 22 & 0,0704 \\
\hline \multirow{3}{*}{ Generator } & 1 & 132 & 55 & 40 & 0,2904 \\
Compartment & 2 & 100.6 & 74.6 & 95 & 0,7130 \\
& 3 & 35 & 74.6 & 40 & 0,1044 \\
\hline
\end{tabular}

The generator compartment divided into sections and fuel tank are seen in Figure 9. For optimal battery placement calculations, the generator room is divided into three sections plus the fuel tank is taken into account. Dimensions of the sections and fuel tank are given in Table I.

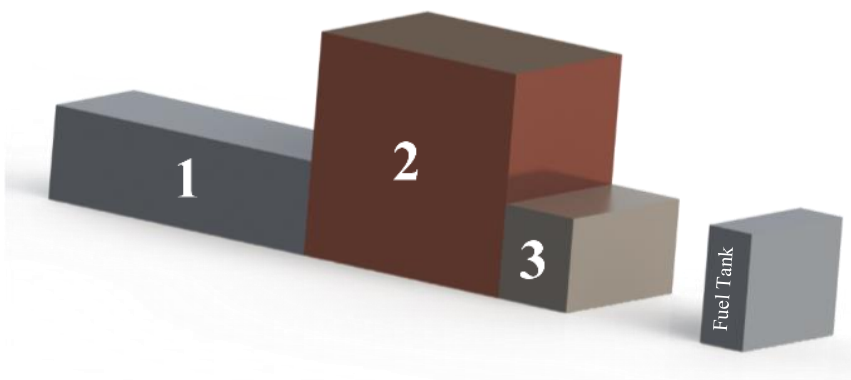

Fig.9. Generator compartment in sections and fuel tank 


\section{A. Battery Casing Type Determination}

In this study, prismatic and 18650 packaged batteries are handled within the framework of technical competencies. When a battery pack of $110 \mathrm{kWh}$ is made from prismatic batteries with different cell capacities that can be found commercially; volume and weight values are obtained as presented in Table II. As seen in Figure 10, even when using CALB SE200AHA battery which is the most suitable type in terms of power/weight ratio; the weight of a $110 \mathrm{kWh}$ battery pack calculated as 991 $\mathrm{kg}$. So, this is $152.5 \%$ higher than the weight constraint of 650 $\mathrm{kg}$. and cannot be used.

In addition, if the electrical and thermal harness on the batteries are also taken into account; the weight to be added to the vehicle exceeds one ton.

TABLE II DATASHEET DATA OF DIFFERENT TYPE BATTERIES FOR A 555 V PACK

\begin{tabular}{|c|c|c|c|c|c|c|c|c|c|}
\hline \multirow[b]{2}{*}{$\begin{array}{c}\text { Battery } \\
\left(\text { LiFePO}_{4}\right)\end{array}$} & \multirow[b]{2}{*}{$\begin{array}{c}\text { Capacity } \\
\text { (Ah) }\end{array}$} & \multirow[b]{2}{*}{$\begin{array}{c}\text { Volume } \\
\left(\mathrm{m}^{3}\right)\end{array}$} & \multirow[b]{2}{*}{$\begin{array}{c}\text { Cell } \\
\text { Voltage } \\
\text { (V) }\end{array}$} & \multirow[b]{2}{*}{$\begin{array}{c}\text { Weight } \\
\text { (kg) }\end{array}$} & \multirow[b]{2}{*}{$\begin{array}{l}\text { Power } \\
\text { (kWh) }\end{array}$} & \multicolumn{4}{|c|}{555 V Pack } \\
\hline & & & & & & $\begin{array}{c}\text { Total } \\
\text { Voltage } \\
\text { (V) }\end{array}$ & $\begin{array}{c}\text { Number } \\
\text { of Cells }\end{array}$ & $\begin{array}{c}\text { Total } \\
\text { Power } \\
\text { (kWh) } \\
\end{array}$ & $\begin{array}{c}\text { Total } \\
\text { Weight } \\
(\mathrm{kg}) \\
\end{array}$ \\
\hline WB-LYP40AHA & 40 & $9.89 \times 10^{-4}$ & 3.2 & 1.6 & 0.148 & 555 & 174 & 22.2 & 278.4 \\
\hline WB-LYP6OAHA & 60 & $1.41 \times 10^{-3}$ & 3.2 & 2.3 & 0.222 & 555 & 174 & 33.3 & 400.2 \\
\hline WB-LYP100AHA & 100 & $2.67 \times 10^{-3}$ & 3.2 & 3.3 & 0.37 & 555 & 174 & 55.5 & 574.2 \\
\hline WB-LYP130AHA & 130 & $3.5 \times 10^{-4}$ & 3.2 & 5.2 & 0.481 & 555 & 174 & 72.15 & 904.8 \\
\hline WB-LYP160AHA & 160 & $3.6 \times 10^{-4}$ & 3.2 & 5.8 & 0.592 & 555 & 174 & 88.8 & 1009.2 \\
\hline CALB CA180FI - & 180 & $4.5 \times 10^{-3}$ & 3.2 & 5.8 & 0.666 & 555 & 174 & 99.9 & 1009.2 \\
\hline CALB SE200AHA & 200 & $3.06 \times 10^{-4}$ & 3.2 & 5.7 & 0.74 & 555 & 174 & 111 & 991.8 \\
\hline WB-LYP300AHA & 300 & $6.2 \times 10^{-3}$ & 3.2 & 10 & 1.11 & 555 & 174 & 166.5 & 1740 \\
\hline
\end{tabular}

Considering that the generator weighs only $600 \mathrm{~kg}$ and the full weight of the fuel tank is $50 \mathrm{~kg}$, the use of prismatic batteries in this study and placing them in the generator compartment is not possible due to the weight constraint. Therefore, in the continuation of the study, calculations will be made for 18650 case batteries.

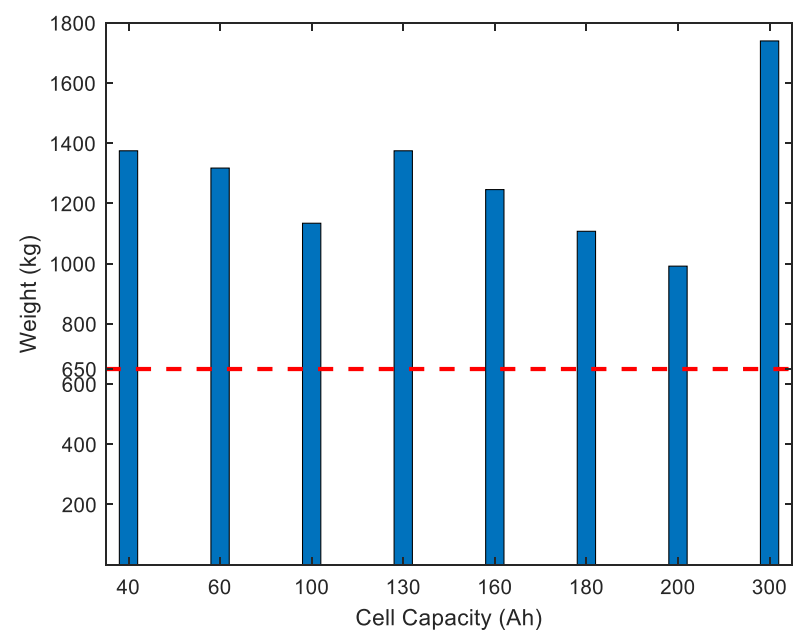

Fig.10. Weight to capacity comparison for $110 \mathrm{kWh}$ or 555 Volt prismatic battery pack

\section{B. Optimal Bin Packing}

In this study, it was aimed to optimally place the 18650 battery group in the generator room. This problem is a wellknown problem, named as Optimal Bin Packing problem which is classified as NP-hard problem [33]-[38]. Every battery pack numbered $i$ has three dimensions depth, width and height; represented as $\ell_{1 i}, \ell_{2 i}, \ell_{3 i}(i \in I)$. Each bin (compartment section) represented by $b$; also has three dimensions $D_{X}, W_{Y}$ and $H_{Z}$ where $\mathrm{X}, \mathrm{Y}$, and $\mathrm{Z}$ represent the axes of a Cartesian coordinate system. All battery packs and sections are assumed in rectangular form. Each battery pack has 6 rectangular facets. But there are only 3 distinct facets because opposing facets are identical. This means each of the three facets can be rotated orthogonally to obtain a new configuration; resulting in 6 different rotation configurations. The orientation of a pack with respect to the container section and the coordinate system is characterized by a binary variable, $\sigma$ as in equation (1).

$$
\sigma_{a i}^{A}:=\left\{\begin{array}{l}
1 ; \text { if pack } i \text { is placed with axis } a \\
\text { parallel to axis } A \text { of the section } \\
0 ; \text { otherwise }
\end{array}\right.
$$

For each $i \in I$, for every axis $a \in O_{\text {Pack }}:=\{1,2,3\}$ of a battery pack, and for every axis $A \in O_{\text {Section }}:=\{X, Y, Z\}$ of section six different orientations are possible. Thus, $i^{\text {th }}$ battery packs orthogonal placement can be written as;

$$
\begin{gathered}
\sum_{A \in O_{S}} \sigma_{1 i}^{A} \leq 1, \sum_{A \in O_{S}} \sigma_{2 i}^{A}=\sum_{A \in O_{S}} \sigma_{1 i}^{A} \\
\sum_{A \in O_{P}} \sigma_{a i}^{A}=\sum_{A \in O_{S}} \sigma_{1 i}^{A} ; \forall A \in O_{S}
\end{gathered}
$$


If $\sum_{A \in O_{S}} \sigma_{1 i}^{A}=1$, this means an edge of pack $i$ is parallel to the one edge of the section. If $\sum_{A \in O_{S}} \sigma_{1 i}^{A}=0$, this means pack $i$ is not placed in the section. The center point of a pack is taken as the allocation point $\left(x_{i}^{X}, x_{i}^{Y}, x_{i}^{Z} \in \mathbb{R}\right)$. This coordinate has to fulfill at least non-overlapping and the containment conditions.

$$
\ell_{a i}:=\frac{1}{2} L_{a i} ; \quad a \in O_{P}
$$

By using equation (4) the containment condition can be written as:

$$
\sum_{a \in O_{P}} \sigma_{a i}^{A} \ell_{a i} \leq x_{i}^{A} \leq \sum_{a \in O_{P}} \sigma_{a i}^{A}\left(D_{A}-\ell_{a i}\right) ; A \in O_{S}
$$

A binary variable is defined to model the non-overlapping condition. For each direction $A \in O_{c}$ and each pair of packs numbered $i$ and $j$ :

$$
\rho_{i j}^{A}:=\left\{\begin{array}{c}
1 ; \text { pack } i \text { has to be placed before pack } \\
j \text { in direction } A \\
0 ; \text { otherwise }
\end{array}\right.
$$

So, the non-overlapping condition for $i, j \in I, i<j$ and $A \in$ $O_{c}$ can be modelled with the following restrictions.

$$
\begin{gathered}
D_{A} \rho_{i j}^{A}+\sum_{a \in O_{P}} \sigma_{a i}^{A} \ell_{a i}-\sum_{a \in O_{P}} \sigma_{a i}^{A}\left(D_{A}-\ell_{a i}\right) \\
\leq x_{i}^{A}-x_{j}^{A} \\
\leq \sum_{a \in O_{P}} \sigma_{a i}^{A}\left(D_{A}-\ell_{a i}\right)-\sum_{a \in O_{P}} \sigma_{a i}^{A} \ell_{a i}-D_{A} \rho_{i j}^{A} \\
\sum_{A \in O_{S}}\left(\rho_{i j}^{A}+\rho_{j i}^{A}\right) \leq \sum_{A \in O_{S}} \sigma_{1 i}^{A}, \\
\sum_{A \in O_{S}}\left(\rho_{i j}^{A}+\rho_{j i}^{A}\right) \leq \sum_{A \in O_{S}} \sigma_{1 j}^{A} \\
\sum_{A \in O_{S}} \sigma_{1 i}^{A}+\sum_{A \in O_{S}} \sigma_{1 j}^{A} \leq 1+\sum_{A \in O_{S}}\left(\rho_{i j}^{A}+\rho_{j i}^{A}\right)
\end{gathered}
$$

Here, equation (6) represents a conditions which ensures the minimum distance between allocated packs. Similarly, equation (7) and equation (8) represents a condition that limits $\sigma$ and $\rho$ variables to define a relevant combination of packs. From equation (4) and equation (6) one can write equation (9) in order to model the non-overlapping packs.

$$
\begin{gathered}
\sum_{a \in O_{P}} \sigma_{a i}^{A} \ell_{a i}-\sum_{a \in O_{P}} \sigma_{a j}^{A}\left(D_{A}-\ell_{a j}\right) \leq x_{i}^{A}-x_{j}^{A} \\
\leq \sum_{a \in O_{P}} \sigma_{a i}^{A}\left(D_{A}-\ell_{a i}\right)-\sum_{a \in O_{P}} \sigma_{a j}^{A} \ell_{a j}
\end{gathered}
$$

$$
\sum_{i \in I} g_{i}\left(\sum_{A \in O_{S}} \sigma_{a i}^{A}\right)
$$

\begin{tabular}{|c|c|}
\hline & FFD Pseudo Code \\
\hline \multicolumn{2}{|c|}{ 1: Sort All object in decreasing order } \\
\hline \multicolumn{2}{|c|}{ 2: for All objects $i=1,2, \ldots, n$ do } \\
\hline \multicolumn{2}{|c|}{ 3: $\quad$ for All bins $j=1,2, \ldots$ do } \\
\hline 4: & if Object $i$ fits in bin $j$ then \\
\hline 5: & Pack object $i$ in bin $j$. \\
\hline 6: & Break the loop and pack the next object. \\
\hline 7: & end if \\
\hline 8: & end for \\
\hline & if Object $i$ did not fit in any available bin then \\
\hline 10: & Create new bin and pack object $i$. \\
\hline 11: & end if \\
\hline 12: & nd for \\
\hline
\end{tabular}

where $g_{i}$ denotes the volume of pack $i$. This integer linear programming problem needs to be solved with the objective function equation (10) and restrictions equation (2), equation (8) for all $i, j \in I, i<j$. In order to solve this problem first fit decreasing (FFD) algorithm is used [39]-[41]. The pseudocode of the FFD algorithm is presented in Table III. To apply this algorithm to the problem an open-source solver named "CLP Spreadsheet Solver" is used. [42], [43].

\section{TABLE III FFD PSEUDO CODE}

\section{Results AND Discussions}

Due to the technical specification requirements of the operator firm, $15 \%$ of battery power is needed to be reserved and a minimum $20 \mathrm{~km}$ range is expected. This study shows that with a battery auxiliary power of $110 \mathrm{kWh}$ trolleybuses can travel $27 \mathrm{~km}$. So, it is found to be $35 \%$ more than the required range as seen in Figure 7.

To achieve this goal this battery pack, have to be placed within the volume of the generator compartment; is found to be $1.1782 \mathrm{~m}^{3}$. A 18650 packed battery's volume, to fit in a rectangular form, is $2.8 \times 10^{-5} \mathrm{~m}^{3}$. Thus, 42078 batteries can be placed in the compartment. There should be 150 units of 3.7 volt Li-Ion batteries in serial to form a $555 \mathrm{~V}$ battery. A combination of 150 series cells is shown in Figure 11. A pack of 150 batteries will have a $1.8 \mathrm{kWh}$ capacity. To reach a 110 $\mathrm{kWh}$ capacity on a vehicle there should be 61 packs in parallel. To sum up, in order to fulfill the technical specs, a vehicle should have 150s61p of $3.7 \mathrm{~V}, 3250 \mathrm{mAh} 18650$ batteries. That means 9150 battery cells which are less than the compartment capacity. So, electronics and the heating-cooling system can easily be installed in the same area.

According to the capacity calculations and voltage 
constraint, the batteries must consist of a minimum of 150 series cells. Therefore, different combinations of 150 serial cells were evaluated for optimal placement in the generator compartment. These combinations are $75 \times 2,50 \times 3,30 \times 5,25 \times 6$ and $15 \times 10$ as shown in Figure 11. The dimensions of these five packages, made up of 18650 batteries, are given in Table IV.

TABLE IV BATTERY PACK TYPE DIMENSIONS

\begin{tabular}{lcccc}
\hline \multicolumn{5}{c}{ Dimension (cm) } \\
\cline { 3 - 5 } & & L & W & H \\
\hline & $2 \times 75$ & 150 & 4 & 7 \\
Battery Pack & $3 \times 50$ & 100 & 6 & 7 \\
Type & $5 \times 30$ & 60 & 10 & 7 \\
& $6 \times 25$ & 50 & 12 & 7 \\
& $10 \times 15$ & 30 & 20 & 7 \\
\hline
\end{tabular}

The battery, which consists of 150 serial cells in total, should have a capacity of $110 \mathrm{kWh}$, which is the minimum capacity constraint of this study. For this, a minimum of 61 parallel connections is required. The 61 parallel connections we obtained here have been identified as another constraint for optimal placement.

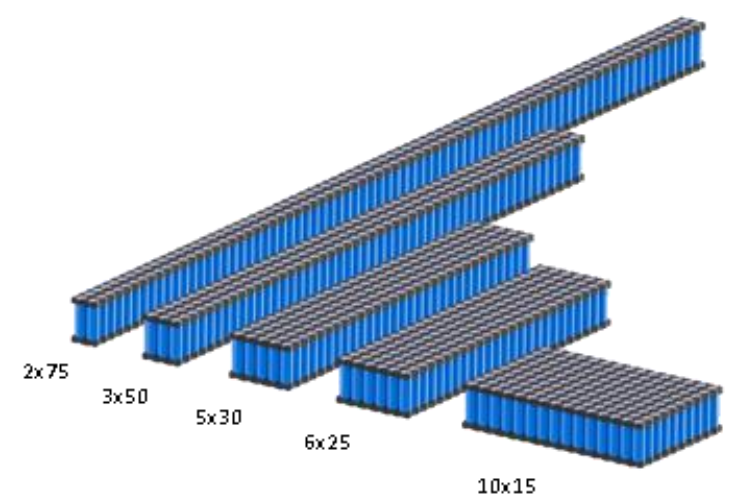

Fig.11. 150 Cells Li-Ion batteries in different packing combinations

In order to make calculations with the CLP Spread Sheet, the generator compartment was taken into account as three separate containers as Section 1, Section 2 and Section 3 as shown in Figure 9. In addition, since the fuel tank will also be removed, this section has also been evaluated for battery installation. At this point to solve that multi-objective optimization problem all constraints and objectives were determined. Hence, CLP Spread Sheet is run with the dimensions in Table I and Table IV, to provide minimum $110 \mathrm{kWh}$ power, 555 Volts voltage, by fulfilling a maximum $650 \mathrm{~kg}$ weight constraint with an optionally minimum number of different battery pack types. The results obtained are presented in Table V.
TABLE V THE OPTIMAL SOLUTION

\begin{tabular}{lccc}
\hline \multicolumn{4}{c}{ Optimal Placement } \\
\cline { 3 - 4 } & & PCs & Kg \\
\hline & $2 \times 75$ & 0 & 0 \\
Battery Pack & $3 \times 50$ & 53 & 397,5 \\
Type & $5 \times 30$ & 42 & 240 \\
& $6 \times 25$ & 0 & 0 \\
& $10 \times 15$ & 0 & 0 \\
\hline Total & & $\mathbf{9 5}$ & $\mathbf{6 3 7 . 5}$ \\
\hline
\end{tabular}

The optimal battery group, calculated to be $637.5 \mathrm{~kg}$ in weight, meets the $650 \mathrm{~kg}$ weight restriction. In addition, a minimum number of different battery pack types are targeted for cost and maintenance convenience. As a result of optimization, it has been shown that optimal placement can be made using only two different types of battery packs, 3x50 and $5 \times 30$.

\section{CONCLUSION}

In this study, an analysis was performed to replace the diesel generator with more environmentally friendly and efficient lithium batteries for the trolleybus vehicles operated in Malatya city. Total battery pack capacity of second phase vehicles, generator compartment plus fuel tank volume, total weight and voltage of the diesel generator are taken as design restrictions. It is known that the battery group should have a capacity of 110 $\mathrm{kWh}$ because it is suitable for operation and is requested by the operator company for range considerations. For this purpose, a number of battery cells required to create a battery that will meet the design criteria, has been determined by the calculations made with the field data taken from the data logger of the vehicle. With the developed software and hardware, different simulation scenarios were analyzed one by one, resulting in the determination of cell chemistry and cell count. It has been shown numerically that the battery to be constructed using available prismatic batteries with the determined number of cells, does not meet design restrictions. For this reason, the study conducted with 18650 case batteries. The placement of battery packs in the generator compartment (bin loading problem) is defined as a linear integer programing problem with volume and weight restrictions. In order to solve that, first-fit descending heuristic algorithm is used. Finally, the shape and layout optimization of the cell packages that will be placed in the generator compartment has been made. According to the results obtained, 95 parallel packs, composed of only $3 \times 50$ and $5 \times 30$ packages, can be placed in the generator compartment. Using only two combinations of battery packs leads to cost, application and maintenance efficiency. With this study, it is shown that such conversion can be done within the requisitions of public transportation operating company. It is evaluated that the method used in this study can also be used in electrification applications to be made in the future. 
BALKAN JOURNAL OF ELECTRICAL \& COMPUTER ENGINEERING, Vol. 9, No. 1, January 2021

\section{ACKNOWLEDGMENT}

This study is supported by Research Fund of Inonu University with Project Number: FOA-2018-1358 and Malatya Metropolitan Municipality Public Transport Inc.

\section{REFERENCES}

[1] L. A. Manwaring, The Observer's Book of Automobiles, 12th Ed. Library of Congress catalog card \# 62-9807, 1966.

[2] M. Guarnieri, "The Big Jump from the Legs of a Frog [Historical],” IEEE Ind. Electron. Mag., vol. 8, no. 4, pp. 59-61,69, 2014, doi: 10.1109/MIE.2014.2361237.

[3] M. Guarnieri, "Looking back to electric cars," in 2012 Third IEEE HISTory of ELectro-technology CONference (HISTELCON), 2012, pp. 1-6, doi: 10.1109/HISTELCON.2012.6487583

[4] F. Maloberti and A. C. Davie, A Short History of Circuits and Systems: From Green, Mobile, Pervasive Networking to Big Data Computing. River Publishers, 2016.

[5] L. Brunton, "The trolleybus story," IEE Rev., vol. 38, no. 2, pp. 57-61(4), 1992, [Online]. Available: https://digitallibrary.theiet.org/content/journals/10.1049/ir_19920024.

[6] U. Kreutzer and E. Blocher, "On the road - with electric power From the trolleybus to the eHighway." https://new.siemens.com/global/en/company/about/history/news/onthe-road-with-electric-power.html (accessed Mar. 26, 2020).

[7] L. J. Brunton, "Why not the trolleybus?," IET Conf. Proc., pp. 5-5(1), 2000, [Online]. Available: https://digitallibrary.theiet.org/content/conferences/10.1049/ic_20000265.

[8] C. ELMAS, U. GUVENC, and M. U. DOĞAN, "Tire-Road Friction Coefficient Estimation and Experimental Setup Design of Electric Vehicle," Balk. J. Electr. Comput. Eng., vol. 3, pp. 202-207, Dec. 2015, Accessed: Dec. 06, 2020. [Online]. Available: https://dergipark.org.tr/tr/pub/bajece/issue/36579/415720\#article_cite.

[9] S. Barsali, A. Bechini, R. Giglioli, and D. Poli, "Storage in electrified transport systems," in 2012 IEEE International Energy Conference and Exhibition (ENERGYCON), 2012, pp. 1003-1008, doi: 10.1109/EnergyCon.2012.6347716.

[10] S. Tica, S. Filipović, and Predrag!, "Development of Trolleybus Passenger Transport Subsystems in Terms of Sustainable Development and Quality of Life in Cities."

[11] L. C. G. Freitas, G. B. Lima, F. A. S. Gonçalves, G. A. Melo, C. A. Canesin, and L. C. de Freitas, "A novel single-phase HPF hybrid rectifier suitable for front-end trolleybus systems," in 2009 Brazilian Power Electronics Conference, 2009, pp. 619-626, doi: 10.1109/COBEP.2009.5347751.

[12] T. Held and L. Gerrits, "On the road to electrification - A qualitative comparative analysis of urban e-mobility policies in 15 European cities," Transp. Policy, vol. 81, pp. 12-23, 2019, doi: https://doi.org/10.1016/j.tranpol.2019.05.014.

[13] M. Glotz-Richter and H. Koch, "Electrification of Public Transport in Cities (Horizon 2020 ELIPTIC Project)," Transp. Res. Procedia, vol. 14, pp. 2614-2619, 2016, doi: https://doi.org/10.1016/j.trpro.2016.05.416.

[14] N. Medimorec, "E-Mobility Trends and Targets." [Online]. Available: https://slocat.net/e-mobility/.

[15] M. Bartłomiejczyk, J. Dombrowski, M. Połom, and O. Wyszomirski, Handbook Conversion of a Diesel Engine Bus. Gdyni: Gmina Miasta Gdyni, 2012.

[16] L. Bertoni, H. Gualous, D. Bouquain, D. Hissel, M.-. Pera, and J.-. Kauffmann, "Hybrid auxiliary power unit (APU) for automotive applications," in Proceedings IEEE 56th Vehicular Technology Conference, 2002, vol. 3, pp. 1840-1845 vol.3, doi: 10.1109/VETECF.2002.1040535.

[17] UNECE, General construction of buses and coaches. Europe, 2020.

[18] B. Ku and J. Liu, "Converter-Switching Surges: Railroad Vehicle Power Converter Impact Studies," IEEE Veh. Technol. Mag., vol. 7, no. 3, pp. 57-66, 2012, doi: 10.1109/MVT.2012.2203409.

[19] K. Rajashekara and Y. Jia, "An induction generator based auxiliary power unit for power generation and management system for more electric aircraft," in 2016 IEEE Energy Conversion Congress and Exposition (ECCE), 2016, pp. 1-7, doi: 10.1109/ECCE.2016.7854849.

[20] D. Zhang, J. Jiang, L. Y. Wang, and W. Zhang, "Robust and Scalable Management of Power Networks in Dual-Source Trolleybus Systems: A
Consensus Control Framework," IEEE Trans. Intell. Transp. Syst., vol. 17, no. 4, pp. 1029-1038, 2016, doi: 10.1109/TITS.2015.2492564.

[21] VT/RTSC - Rail Transportation Standards Committee, IEEE Recommended Practice for Terminology Used for Direct Current Electric Transit Overhead Contact Systems. 2019.

[22] J. Joyce, British Trolleybus Systems. London: Littlehampton Book Services Ltd, 1986.

[23] C. S. Dunbar, Buses, Trolleys and Trams. Octopus Publishing Group, 2004

[24] Wikipedia, "List of trolleybus systems," 2020. https://en.wikipedia.org/wiki/List_of_trolleybus_systems.

[25] P. Stepanov, "Characteristics of construction and operation of trolleybus systems in the wo," Pr. Kom. Geogr. Komun. PTG, vol. 22, no. 3, pp. 64-72, 2019, doi: DOI 10.4467/2543859XPKG.19.018.11284.

[26] Wikipedia, "Public transport in Istanbul," 2020. https://en.wikipedia.org/wiki/Public_transport_in_Istanbul.

[27] Rayhaber, "Malatya new Trambus line," 2013. https://en.rayhaber.com/2013/04/malatya-yeni-trambus-hatti/.

[28] "Trolleybus usage by country." https://en.wikipedia.org/wiki/Trolleybus_usage_by_country\#Turkey_2 (accessed Mar. 26, 2020).

[29] J. Choi, J. Jeong, Y. Park, and S. W. Cha, "Evaluation of regenerative braking effect for E-REV bus according to characteristic of driving cycle," Int. J. Precis. Eng. Manuf. Technol., vol. 2, no. 2, pp. 149-155, 2015, doi: 10.1007/s40684-015-0019-6.

[30] D. Perrotta, B. Ribeiro, R. J. F. Rossetti, and J. L. Afonso, "On the Potential of Regenerative Braking of Electric Buses as a Function of Their Itinerary," Procedia - Soc. Behav. Sci., vol. 54, pp. 1156-1167, 2012, doi: https://doi.org/10.1016/j.sbspro.2012.09.830.

[31] E. Sindi, L. Y. Wang, M. Polis, G. Yin, and L. Ding, "Distributed Optimal Power and Voltage Management in DC Microgrids: Applications to Dual-Source Trolleybus Systems," IEEE Trans. Transp. Electrif., vol. 4, no. 3, pp. 778-788, 2018, doi: 10.1109/TTE.2018.2844367.

[32] Opperhill, "Real-Time CAN bus data recorder with SD card," 2019. https://copperhilltech.com/blog/realtime-can-bus-data-recorder-withsd-card/.

[33] A. Bortfeldt and G. Wäscher, "Container Loading Problems - A Stateof-the-Art Review," Otto-von-Guericke University Magdeburg, Faculty of Economics and Management, 2012. doi: DOI:

[34] M. R. Garey and D. S. Johnson, Computers and Intractability; A Guide to the Theory of NP-Completeness. USA: W. H. Freeman \&amp; Co., 1990.

[35] E. Dube, "Optimizing Three-Dimensional Bin Packing Through Simulation," 2006

[36] R. Lewis, "A general-purpose hill-climbing method for order independent minimum grouping problems: A case study in graph colouring and bin packing," Comput. Oper. Res., vol. 36, no. 7, pp. 2295-2310, Jul. 2009, doi: 10.1016/J.COR.2008.09.004.

[37] G. Fasano, "Cargo Analytical Integration in Space Engineering: A Three-dimensional Packing Model BT - Operational Research in Industry," T. A. Ciriani, S. Gliozzi, E. L. Johnson, and R. Tadei, Eds. London: Palgrave Macmillan UK, 1999, pp. 232-246.

[38] M. Padberg, "Packing small boxes into a big box," Math. Methods Oper. Res., vol. 52, no. 1, pp. 1-21, 2000, doi: 10.1007/s001860000066.

[39] B. S. Baker, "A new proof for the first-fit decreasing bin-packing algorithm," J. Algorithms, vol. 6, no. 1, pp. 49-70, 1985, doi: https://doi.org/10.1016/0196-6774(85)90018-5.

[40] W. T. Rhee, "Stochastic Analysis of a Modified First Fit Decreasing Packing," Math. Oper. Res., vol. 16, no. 1, pp. 162-175, Dec. 1991, [Online]. Available: http://www.jstor.org/stable/3689854.

[41] G. Dósa, "The Tight Bound of First Fit Decreasing Bin-Packing Algorithm is $F F D(I) \leq 11 / 9 O P T(I)+6 / 9$," in Proceedings of the First International Conference on Combinatorics, Algorithms, Probabilistic and Experimental Methodologies, 2007, pp. 1-11.

[42] G. Erdoğan, "CLP Spreadsheet Solver." https://people.bath.ac.uk/ge277/clp-spreadsheet-solver/.

[43] ]A. Ochoa Ortiz-Zezzatti, G. Rivera, C. Gómez-Santillán, and B. Sánchez-Lara, Eds., Handbook of Research on Metaheuristics for Order Picking Optimization in Warehouses to Smart Cities. IGI Global, 2019. 


\section{BIOGRAPHIES}

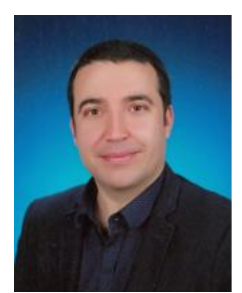

İSMAİL CAN DÍKMEN received the B.S. and M.S. degrees in Electronics Engineering from the National Defense University and Aeronautics and Space Technologies Institute, in 2002 and 2007 respectively. He is continuing his $\mathrm{PhD}$ studies on intelligent battery management systems for electric vehicles at Inonu University. Currently he is an instructor at Electric Vehicle Technologies department of Inonu University OSB vocational school. His research interests include electric vehicles, battery management systems, control theory, control system design, electronic circuit design, optimization methods and machine learning.

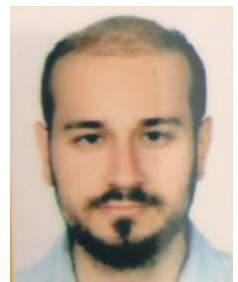

YUNUS EMRE EKİCi is currently an instructor at Electric Vehicle Technologies department of Inonu University OSB vocational school. $\mathrm{He}$ is continuing his $\mathrm{PhD}$ studies. His research interests include electric vehicles, traction batteries, power electronics, powertrain systems, control theory and electric vehicles charging systems.

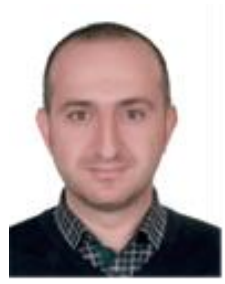

TEOMAN KARADAG Assist. Prof. in Department of Electrical and Electronics Engineering, Inonu University of Malatya, Turkey. He continues to work in the department, where he graduated, as an Asst. Professor Dr. since 2015. High and Low Frequency Electromagnetic Fields and Applications, Electric Vehicles and Battery Management Systems, Electric Vehicle Charging Stations are the main fields of his study.

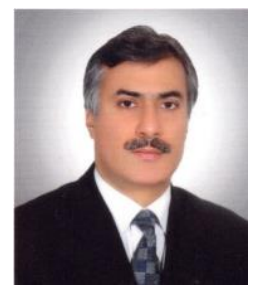

TAHMURAZ ABBASOV was born in Karabag, Azerbaijan, 1958. He received the B.Sc. and the M.Sc. degrees from Moscow Automechanical Institute (Moscow State Technical University, MAMI) and the Ph.D. degree from University of Azerbaijan State Petrol Academy and Azerbaijan National Scientific Academy, all in Electrical Engineering, in 1981, 1991 respectively. Currently, he is a Professor of Electrical Engineering at Inonu University. He is also an academic member of American Chemical Society, $\mathrm{He}$ is member of two international journals. His research interests are in the area of Electromagnetic Fields and Technology, Magneto hydro Dynamics and Magnetic Fluids, Bioelectromagnetics.

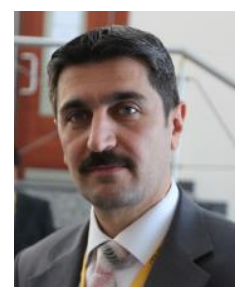

SERDAR ETHEM HAMAMCI received the B.S. degree in Electronics Engineering from Erciyes University in 1992 and the M.S. and PhD. degrees in Electrical-Electronics Engineering from Firat University in 1997 and 2002 respectively. He is currently full professor at Electrical-Electronics Engineering Department at Inonu University, Malatya, Turkey. His research interest includes electric vehicles, control system design, fractional order systems, memristive systems and data mining. 